\title{
テラヘルツ電磁波による半導体ウェーハの 電気的特性の計測・評価*
}

\author{
巨陽*1, 久保田 穂高*2

\section{Measurement and Evaluation of Electrical Properties of Semiconductor Wafer by Terahertz Waves}

\author{
Yang $\mathrm{JU}^{* 3}$ and Hotaka KUBOTA \\ ${ }^{* 3}$ Department of Mechanical Science \& Engineering, Nagoya University, \\ Furo-cho, Chikusa-ku, Nagoya-shi, Aichi, 464-8603 Japan
}

\begin{abstract}
Using a time-domain spectroscopic technique based on the generation and detection of a collimated beam of subpicosecond broadband terahertz pulses, we measured frequency-dependent electrical properties of doped silicon in the terahertz wave range of $0.1-1.2 \mathrm{THz}$. These results are well fit by Drude theory. It is shown that carrier density can be evaluated well by the suggested method.
\end{abstract}

Key Words: Nondestructive Evaluation, Spectrum Analysis, Terahertz Wave, Electrical Property

\section{1. 緒言}

シリコンなどの半導体ウェーハは電子デバイス, 特 に集積回路の基板として利用されている。導電率をは じめとする電気的特性は電子デバイスの電気容量, 抵 抗などに影響を及ほすをめ，半導体の電気的特性はデ バイスを設計するうえで重要なパラメータである。そ のため, 半導体の電気的特性を決定付けるキャリアダ イナミクスの研究(1)〜(3) が盛んに行われてきており, 特にキャリアの緩和時間やプラズマ振動数と同程度の 周波数域であるテラヘルツ領域の研究に強い関心がも たれている.しかし，テラヘルツ時間領域分光法が確 立されて間もないことから，テラヘルツ領域の半導体 の電気的特性に関する研究はまだ十分に行われていな い状況にある。

従来, 導電率計測には四探針法が広く用いられてき た。四探針法は，4本金属製プローブを被測定物の表 面に接触させ，測定を行う．外側 2 本のプローブ間に 定電流を流し, 内側 2 本のプローブ間における電位差

* 原稿受付 2009 年 9 月 30 日。

*1 正員, 名古屋大学 ( 464-8603 名古屋市千種区不老町).

*2 中部電力(株) (画 437-1695 御前崎市佐倉 5561).

E-mail : ju@mech.nagoya-u.ac.jp
を計測することにより比抵抗，あるいは導電率を求め ることができる、しかしながら四探針法による半導体 ウェー八の導電率の測定では, ウェー八の表面を污し たり，傷つけたりする問題がある。また，四探針法に よる導電率測定は接触型であるため, 膨大な生産量の 場合ではオンライン検查を行うことは困難である。ま た，半導体材料のキャリア濃度や電気移動度の評価方 法としては，主にホール効果測定法が用いられている が，この方法では測定の際に試験片と電極端子を溶接 したり，試験片を切断するなど試験片の加工が必要と なるため, 現在の検查方法では半導体部品の全数の検 查は不可能である。また，金属と半導体間の接続では ショットキー障壁が存在し，キャリア濃度が低い場合 など電気特性を正確に計測することが困難である。

そこで, 本研究は以上の状況を踏まえ, テラヘルツ 時間領域分光法を基に，実験結果と適切なキャリア伝 導理論を融合することにより，今まで測定が困難であ ったテラヘルツ電磁波領域の半導体の電気的特性を非 接触・非破壊で測定・評価する技術を提案する.

\section{2. 実 験 方 法}

実験で使用した光路システムを図 1 に示す。本実験 では光伝導アンテナをもつエミッタ,ディテクタによ 
りテラヘルツ波の発生・検出を行った。レーザ発振装 置にはモードロック型の Ti:sapphireレーザ(波長 $790 \mathrm{~nm}$, レーザ出力 $850 \mathrm{~mW}$, 繰り返し周波数 80 $\mathrm{MHz}$ ，パルス幅 $100 \mathrm{fs}$ )を使用した. ポンプ光とプロ ーブ光のエネルギーはそれぞれ $150 \mathrm{~mW}, 50 \mathrm{~mW}$ ，バ イアス電圧 $50 \mathrm{~V}$ の条件で測定した．ポンプ光はロッ クインアンプで信号を検出する際の参照信号を得るた め, ライトチョッパにより $500 \mathrm{~Hz}$ に周波数変調をか けた.ディテクタから発生した電流信号はロックイン アンプで検出した。

エミッタとディテクタの間には 2 枚の放物面鏡を置 き，その間に Si ウェー八試料を挿入し，透過した電磁 波を検出した。今回は抵抗率の異なる 5 種類の試料で 測定を行った．挿入した試料の物性值を表 1 に示す.

透過測定から求めた電磁波の振幅透過率と位相差か ら, 複素屈折率 $(\tilde{n}=n+i x)$ お よび複素誘電率 $\left(\tilde{\varepsilon}=\varepsilon_{1}\right.$ $\left.+i \varepsilon_{2}\right)$ を算出した ${ }^{(4)}$. ここで, 複素屈折率と複素誘電 率は以下の式で結びついている。

$$
\widetilde{\varepsilon}(\omega)=\tilde{n}(\omega)^{2}
$$

さらに，実験プロットにフィッティングする関数とし て,ドルーデの理論式を用いた. ドルーデの理論式は

Table 1 Properties of Si wafers

\begin{tabular}{c|c|c|c}
\hline Thickness $[\mu \mathrm{m}]$ & Resistivity $[\Omega \mathrm{cm}]$ & Mobility $\left[\mathrm{cm}^{2} / \mathrm{Vsec}\right]$ & Carrier concentration[ $\left.\mathrm{cm}^{-3}\right]$ \\
\hline 528 & 0.509 & $1.39 \times 10^{3}$ & $8.82 \times 10^{15}$ \\
349 & 0.883 & $1.51 \times 10^{3}$ & $4.69 \times 10^{15}$ \\
531 & 1.68 & $1.55 \times 10^{3}$ & $2.41 \times 10^{15}$ \\
337 & 2.93 & $1.66 \times 10^{3}$ & $1.28 \times 10^{15}$ \\
355 & 16.5 & $1.76 \times 10^{3}$ & $2.15 \times 10^{14}$ \\
\hline
\end{tabular}

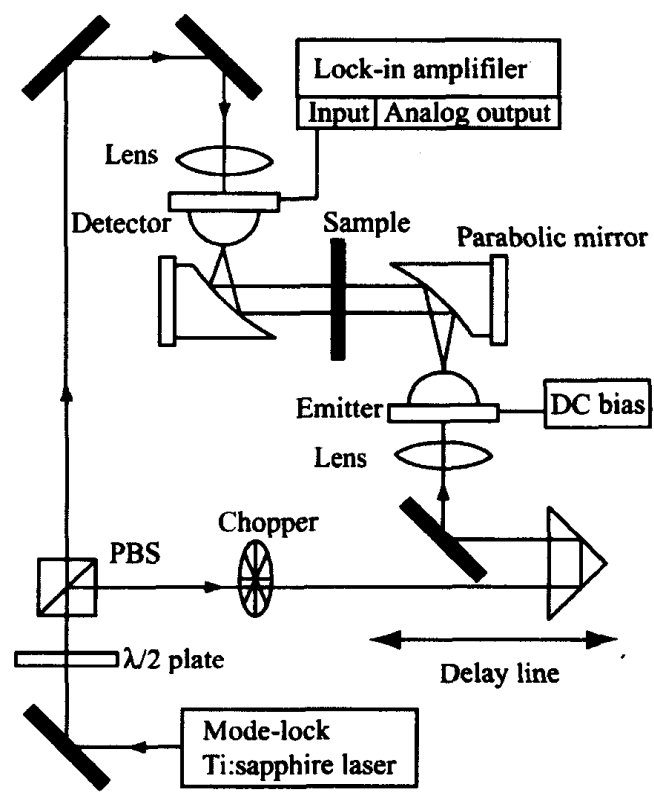

Fig. 1 Schematic diagram of $\mathrm{THz}^{-}$TDS set-up
以下のように表現される.

$$
\widetilde{\varepsilon}(\omega)=\varepsilon_{\infty}-\frac{\omega_{p}^{2}}{\omega^{2}+(i \omega / \tau)}
$$

式 ( 2 )で $\varepsilon_{\infty}$ は高周波の誘電率, $\omega_{p}$ はプラズマ振動 数, $\tau$ は衝突の緩和時間を表している.また, プラズ マ振動数, 衝突の緩和時間はキャリア濃度, 電気移動 度, 直流伝導度と以下の関係がある.

$$
\begin{aligned}
& \omega_{p}^{2}=\frac{N e^{2}}{m \varepsilon_{0}} \ldots \ldots \ldots . . . \\
& \tau=\frac{m \mu}{e} \cdots \ldots \ldots . . . \\
& \sigma_{0}=\frac{N e^{2} \tau}{m}=N e \mu
\end{aligned}
$$

式 ( 3 )〜 ( 5 )で $N$ はキャリア濃度, $e$ は素電荷, $m$ はキャリアの有効質量, $\varepsilon_{0}$ は真空の誘電率, $\mu$ は電気 移動度， $\sigma_{0}$ は直流伝導度を表している.フィッティン グにより求めたドルーデの理論式中の各パラメータを 式 ( 3 ) （5)に代入することで, 試料のキャリア濃度, 電気移動度, 直流伝導度を実験的に推定した。

\section{3. 実 験 結 果}

実験で得られた電磁波の時間波形をフーリエ変換し て得た電場振幅スペクトルを図 2 に示す.図 2 を見る と試料の抵抗率が小さくなるにつれて, 試料を通過す る電磁波の振幅が小さくなっていくことがわかる．ま た, 測定可能な周波数範囲は $0.1 \sim 1.2 \mathrm{THz}$ であっ た.

次に, 5 種類の $\mathrm{Si}$ ウェー八の複素屈折率の実部であ る屈折率の周波数依存性を図 3 に, 複素屈折率の虚部 である消衰係数の周波数依存性を図 4 に示す。プロッ トは実験で求めた值であり, 実線は実験プロットにド ルーデの理論式をフィッティングさせた結果である。 なお,フィッティングに使用した周波数の範囲は $0.176 \sim 1.2 \mathrm{THz}$ である. また, 図 3 , 図 4 のフィッテ イングに使用した理論式の係数值およびそれらの係数

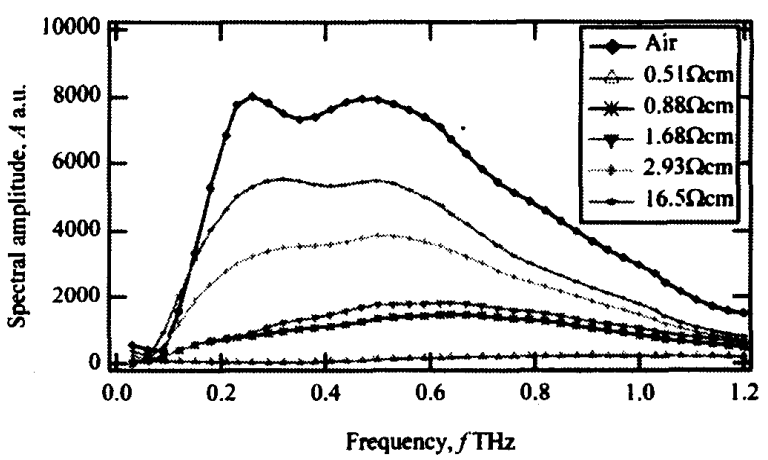

Fig. 2 Amplitude spectra of $\mathrm{THz}$ pulses 
Table 2 Fit parameters used to fit reflective index shown in Fig. 3

\begin{tabular}{c|ccccc}
\hline Material & \multicolumn{5}{|c}{$\mathrm{Si}$} \\
\hline Resistivity $[\Omega \mathrm{cm}]$ & 0.51 & 0.88 & 1.68 & 2.93 & 16.5 \\
\hline$\omega_{\rho}[\mathrm{THz}]$ & 7.80 & 5.08 & 3.83 & 3.89 & 3.19 \\
\hline$\tau[\mathrm{psec}]$ & 0.309 & 0.488 & 0.641 & 0.549 & 0.571 \\
\hline$\varepsilon_{\infty}[\mathrm{psec}]$ & 11.0 & 11.0 & 11.2 & 11.5 & 11.7 \\
\hline$N\left[\times 10^{15} \mathrm{~cm}^{-3}\right]$ & 7.14 & 3.00 & 1.70 & 1.76 & 1.18 \\
\hline$\mu\left[\mathrm{cm}^{2} / \mathrm{vsec}\right]$ & 1470 & 2320 & 3050 & 2610 & 2720 \\
\hline $1 / \sigma_{0}[\Omega \mathrm{cm}]$ & 0.60 & 0.90 & 1.20 & 1.36 & 1.94 \\
\hline
\end{tabular}

Table 3 Fit parameters used to fit extinction coefficient shown in Fig. 4

\begin{tabular}{c|cccc}
\hline Material & \multicolumn{4}{|c}{$\mathrm{Si}$} \\
\hline Resistivity $[\Omega \mathrm{cm}]$ & 0.51 & 0.88 & 1.68 & 2.93 \\
\hline$\omega_{p}[\mathrm{THz}]$ & 10.10 & 7.58 & 5.36 & 4.60 \\
\hline$\tau[\mathrm{psec}]$ & 0.190 & 0.196 & 0.261 & 0.153 \\
\hline$\varepsilon_{\infty}[\mathrm{psec}]$ & 11.7 & 11.3 & 11.3 & 11.6 \\
\hline$N\left[\times 10^{15} \mathrm{~cm}^{-3}\right]$ & 11.8 & 6.68 & 3.54 & 2.46 \\
\hline$\mu\left[\mathrm{cm}^{2} / \mathrm{Vsec}\right]$ & 900 & 930 & 1240 & 730 \\
\hline $1 / \sigma_{0}[\Omega \mathrm{cm}]$ & 0.59 & 1.00 & 1.51 & 3.50 \\
\hline & & & &
\end{tabular}

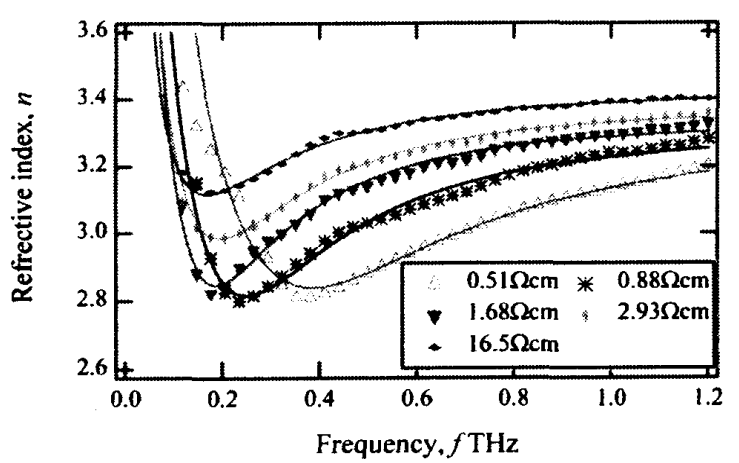

Fig. 3 Analysis results for refractive indexes; solid lines describe Drude theory

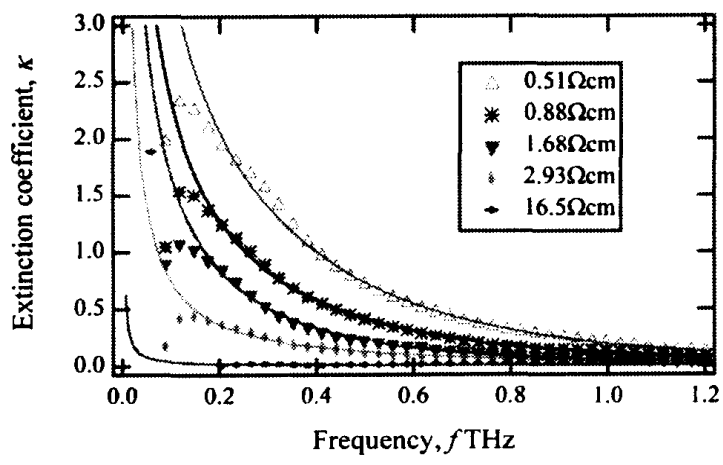

Fig. 4 Analysis results for extinction coefficients; solid lines describe Drude theory
值から算出したキャリア濃度, 移動度, 直流伝導度の 值をそれぞれ表 2 ，表 3 に示す。ただし，表 3 におい て, $16.5 \Omega \cdot \mathrm{cm}$ の試料はデー夕值が小さく,ばらつき が大きいため，フィッティングでよい近似が得られな かったので省略されている。

図 3 から，抵抗率が大きい試料ほど屈折率も大きく なることがわかる、一方, 図 4 から, 抵抗率が大きい ほど，消衰係数は小さくなることがわかる，また，屈 折率, 消衰係数ともに $0.2 \mathrm{THz}$ 以下の低周波数域で は, 変化が急激であり,デー夕に誤差が大きいように 思われる。

次に, 図 3, 図 4 で示した複素㐿折率から算出され た複素誘電率の実部である誘電率の周波数依存性を図 5 に, 複素誘電率の虚部である誘電損失の周波数依存 性を図 6 に示す.また, 図 5 , 図 6 のフィッティング に使用した理論式の係数值およびそれらの係数値から 算出したキャリア濃度, 移動度, 直流伝導度の值をそ れぞれ表 4 , 表 5 に示す.ただし, 表 5 に示す誘電損 失の結果に扔いて, $16.5 \Omega \cdot \mathrm{cm}$ の試料はデー夕值が小 さく，ばらつきが大きいため，よい近似が得られなか ったので省略されている。

図 5 から，抵抗率が大きい試料ほど誘電率も大きい

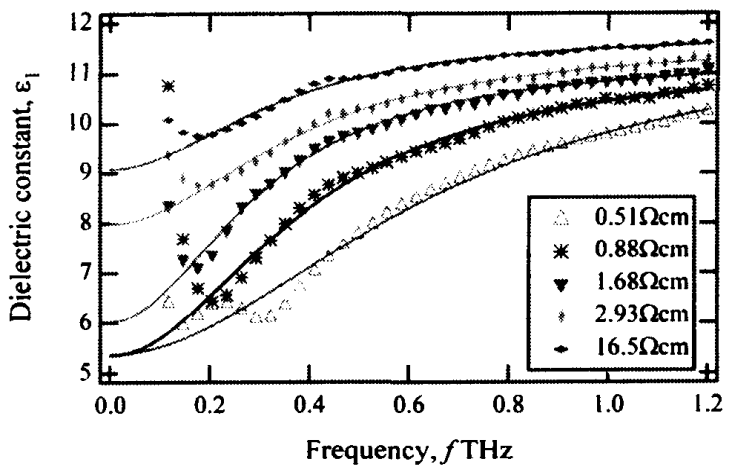

Fig. 5 Analysis results for dielectric constants

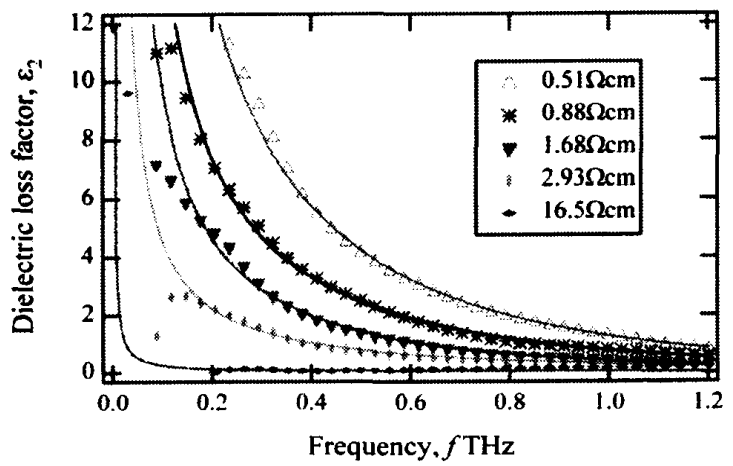

Fig. 6 Analysis results for dielectric loss factors 
Table 4 Fit parameters used to fit dielectric constants shown in Fig. 5

\begin{tabular}{c|ccccc}
\hline Material & \multicolumn{5}{|c}{$\mathrm{Si}$} \\
\hline Resistivity $[\Omega \mathrm{cm}]$ & 0.51 & 0.88 & 1.68 & 2.93 & 16.5 \\
\hline$\omega_{p}[\mathrm{THz}]$ & 10.28 & 6.15 & 4.47 & 4.50 & 3.50 \\
\hline$\tau[\mathrm{psec}]$ & 0.244 & 0.395 & 0.513 & 0.420 & 0.469 \\
\hline$\varepsilon_{\infty}[\mathrm{psec}]$ & 11.7 & 11.3 & 11.3 & 11.5 & 11.8 \\
\hline$N\left[\times 10^{15} \mathrm{~cm}^{-3}\right]$ & 12.3 & 4.40 & 2.32 & 2.35 & 1.42 \\
\hline$\mu\left[\mathrm{cm}^{2} / \mathrm{Vsec}\right]$ & 1160 & 1880 & 2440 & 2000 & 2230 \\
\hline $1 / \sigma_{0}[\Omega \mathrm{cm}]$ & 0.44 & 0.76 & 1.10 & 1.33 & 1.96 \\
\hline
\end{tabular}

Table 5 Fit parameters used to fit dielectric loss factors shown in Fig. 6

\begin{tabular}{c|cccc}
\hline Material & \multicolumn{4}{|c}{$\mathrm{Si}$} \\
\hline Resistivity $[\Omega \mathrm{cm}]$ & 0.51 & 0.88 & 1.68 & 2.93 \\
\hline$\omega_{p}[\mathrm{THz}]$ & 10.00 & 7.76 & 5.59 & 4.83 \\
\hline$\tau[\mathrm{psec}]$ & 0.168 & 0.160 & 0.196 & 0.122 \\
\hline$\varepsilon_{\infty}[\mathrm{psec}]$ & 11.7 & 11.3 & 11.3 & 11.6 \\
\hline$N\left[\times 10^{15} \mathrm{~cm}^{-3}\right]$ & 11.7 & 7.00 & 3.63 & 2.71 \\
\hline$\mu\left[\mathrm{cm}^{2} / \mathrm{Vsec}\right]$ & 800 & 760 & 930 & 580 \\
\hline $1 / \sigma_{0}[\Omega \mathrm{cm}]$ & 0.67 & 1.17 & 1.84 & 3.96 \\
\hline & & & &
\end{tabular}

ことがわかる、一方, 図 6 から，抵抗率が大きい試料 ほど誘電損失は小さくなることがわかる。

次に，ホール測定結果で得られたキャリア濃度, 移 動度と複素誘電率および複素屈折率のデータへのフィ ッティングから得られたキャリア濃度, 移動度の值と を比較したグラフをそれぞれ図 7 , 図 8 に示す。

図 7 を見ると, 複素誘電率および複素屈折率から得 られるキャリア濃度は最も高抵抗率である $16.5 \Omega$ ・ $\mathrm{cm}$ の試料を除いては, ホール効果測定值に比較的近 い值を示している。しかし，高抵抗率側に近づくにつ れて,データ近似值は測定值から徐々にずれていくよ うに見える。一方, 図 8 から, 移動度は複素誘電率お よび複素屈折率から得られたどの值においても測定值 からかなりずれている，また，屈折率および誘電率か ら得られた 2 つの值を比較すると, キャリア濃度およ び移動度に扔いて互いに近い值となっている，同様の ことは虚部である消衰係数および誘電損失から得られ た值にも成り立つ。また，実部の值は測定值よりも高 め, 虚部は測定値よりも低めの值になる傾向が見られ る.

このように複素誘電率の実部，虚部から求められる 值の差異が生じているのは, 複素屈折率の実部, 虚部

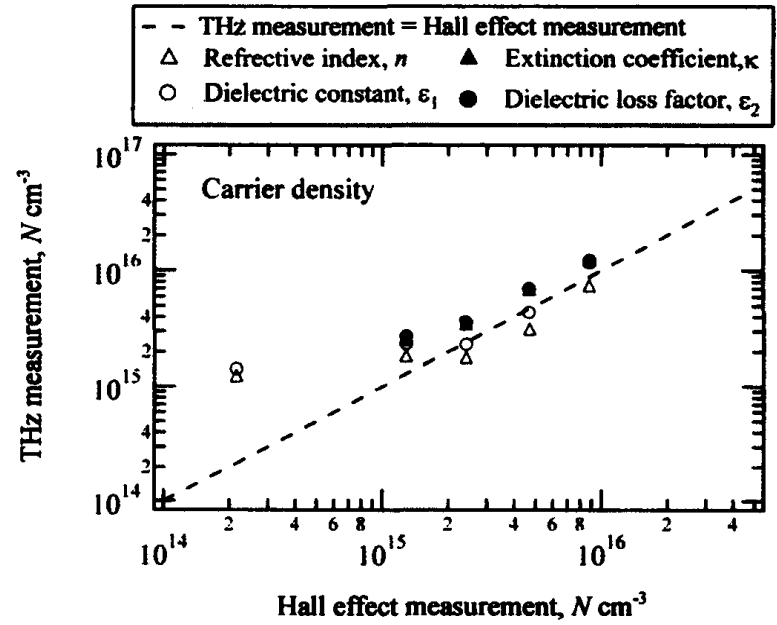

Fig. 7 Comparison between $\mathrm{THz}$ TDS measurement results and Hall effect measurement results for carrier density

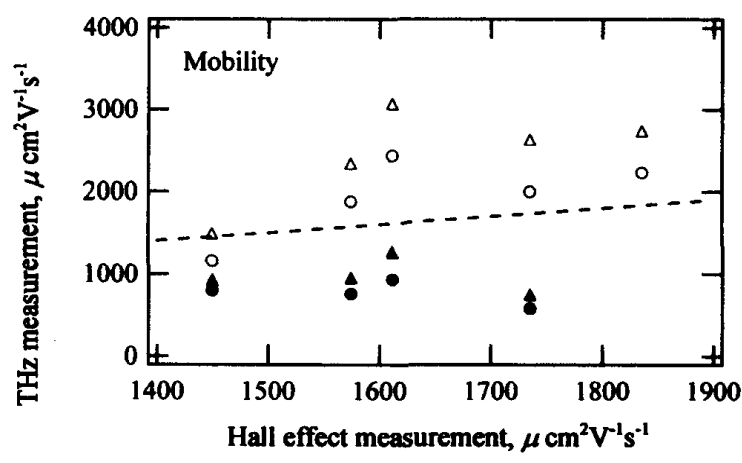

Fig. 8 Comparison between $\mathrm{THz}$ TDS measurement results and Hall effect measurement results for mobility

の值に差異があるためであると考えられる．理論的に は実部，虚部から同一の值が得られるべきであるので, 今回は実部，虚部からそれぞれ得られたキャリア濃度， 移動度の平均值をとって測定値と比較してみた。実部 と虚部の両方から求められたキャリア濃度, 移動度の 平均值とホール効果測定值との比較をそれぞれ図 9 , 図 10 に示す．図 9 を見ると，実部と虚部の平均値を とることで，評価值は測定值により近づく結果となっ た。また，キャリア濃度が高い試料ではよい一致を示 すが，キャリア濃度が低い試料ほど一致しなくなる傾 向がみられる。また，図 10 から，移動度も平均值をと ることで実部および虚部から得られる值よりも測定值 に近づく結果となった。従って，実部と虚部の平均值 を用いることで, より信頼性の高い結果を得られると 考えられる。

キャリア濃度, 移動度の両方で抵抗率 $16.5 \Omega \cdot \mathrm{cm}$ の試料の実験值が測定值と大きく異なる結果となった 


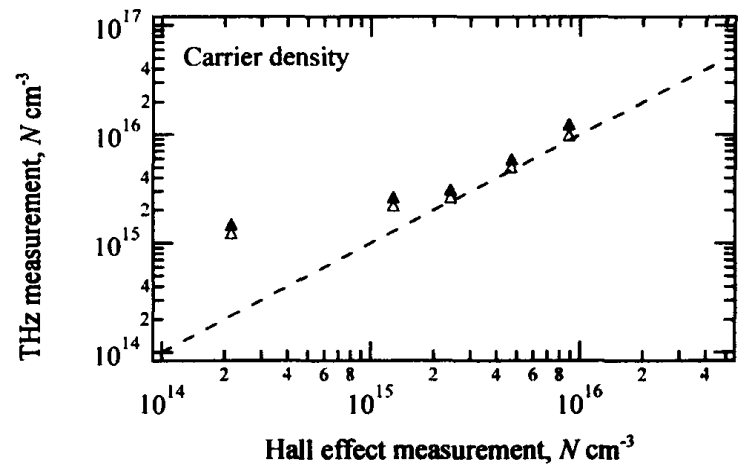

Fig. 9 Comparison between $\mathrm{THz}$ TDS measurement results and Hall effect measurement results for carrier density

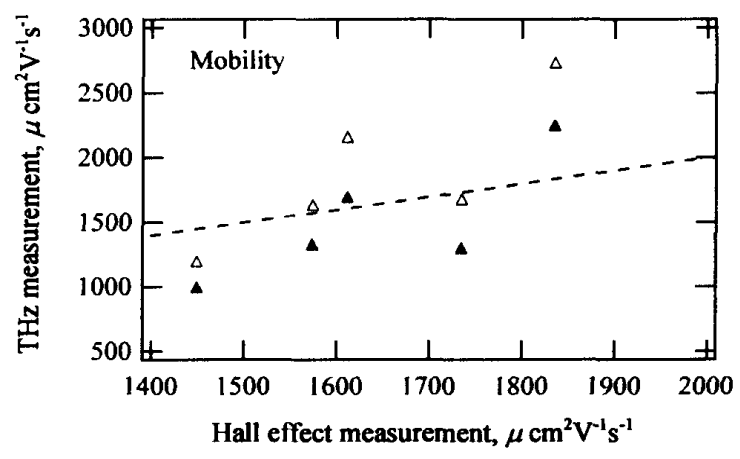

Fig. 10 Comparison between $\mathrm{THz}$ TDS measurement results and Hall effect measurement results for mobility

が，それは試料の抵抗率が大きいのが原因であると考 えられる．高抵抗率の試料では低周波領域から透過率 が高くて, 消哀係数の值の周波数依存性が判断し難い ために, 理論式をフィッティングする際に大きな差異 が生じてしまうと考えられる。このように測定データ の信頼性が劣るために, 本研究で示した測定法は高抵 抗率の半導体試料での電気的特性評価には適さないと 考えられる。

\section{4. 結 論}

（1）抵抗率が異なる 5 種類の $\mathrm{Si}$ ウェーハのテラ ヘルツ波透過测定の結果, 試料の抵抗值によって各試 料の複素屈折率, 複素誘電率の周波数依存には大きな 差異が生じることがうかった。また, それらの周波数 依存性は低周波側で特に変化が大きく, 高周波に近づ くにつれて一定值に漸近していくことがわかつた。

（2）実験で得られた複素誘電率および複素屈折率 のデータにドルーデの理論式をフィッティングするこ とでキャリア濃度や移動度といった物性值を推定でき た.さらに, 実験データのフィッティングから得られ たキャリア濃度, 移動度とホール効果測定で得られた 実測值との比較・検討を行った結果，フィッティング により得られたキャリア濃度は実測値に近い值を示し たが, 移動度はあまり近い值にならなかった。その原 因としては，実験データの精度が足りないということ とドルーデの理論式だけでは半導体の電気伝導の様子 を正確に表せてないということが考えられる。半導体 試料のより高精度な電気的特性の評価のためには, 半 導体中の電子の伝導を模擬したさらに適切な理論の発 見が望まれる。

\section{文献}

(1) Jeon, T. and Grischkowsky, D., Nature of Conduction in Doped Silicon, Physical Review Letters, Vol. 78, No. 6 (1997), pp. 1106-1109.

(2) Fekete, L., Nēmec, H., Kadlec, F., Kuz̄el, P., Stuchlik, J., Fejfar, A. and Kočka, J., Carrier Dynamics in Microcrystalline Silicon Studied by Time-resolved Terahertz Spectroscopy, Journal of Non-Crystalline Solids, Vol. 352, No. 26-27 (2006), pp. 2846-2849.

(3) Beard, M. C., Turner, G. M. and Schmuttenmaer, C. A., Subpicosecond Carrier Dynamics in Low-temperature Grown GaAs as Measured by Time-resolved Terahertz Spectroscopy, Journal of Applied Physics, Vol. 90, No. 12 (2001), pp. 5915-5923.

(4) Tonouchi, M., Terahertz Technology (in Japanese), (2006), pp. 43-44, Ohmsha. 